
\title{
25 Research Square \\ The Effect of the National Brand on High-Tech Exports in Selected Countries
}

\section{Abolfazl Shahabadi ( $\square$ a.shahabadi@alzahra.ac.ir)}

Alzahra University Faculty of Social Sciences and Economics https://orcid.org/0000-0002-9316-8296

\section{Shiva Amjadian}

Azad University: Islamic Azad University

\section{Masoume Shafieian}

Alzahra University

\section{Research}

Keywords: High-Tech Exports, Intellectual Property Rights, National Brand, Real Exchange Rate.

Posted Date: August 10th, 2021

DOl: https://doi.org/10.21203/rs.3.rs-775884/v1

License: (1) This work is licensed under a Creative Commons Attribution 4.0 International License. Read Full License 


\section{Abstract}

High-tech exports play a crucial role on the growth and prosperity of the national economy due to higher added value and higher profitability; however, gaining a competitive advantage and increasing high-tech exports is arduous because of the highly competitive environment in global markets. Also, increasing the value of the national brand through the improvement of foreign customers' mental image of products made in a specific country can play an undeniable role in the increase of customer loyalty and the growth of high-tech exports. Therefore, we intended to evaluate the impact of the national brand on high-tech exports in 14 selected developing countries (sample group) and 12 selected developed and emerging countries (control group) by using panel data and generalized method of moments (GMM), during the period 2011-2018. The results showed the positive and significant impact of the national brand in both groups, but the estimated coefficient is higher in developed and emerging countries. It means that although the improvement of the national brand stimulates the demands for high-tech products from foreign customers, countries that have had more capacity to increase the production and supply of these products have been more successful in meeting the surplus demand created. Therefore, developing countries should take action to improve the national brand, by moving towards a knowledge-based economy, and at the same time, they have to increase their capacity of production and supply of hightech products to be able to meet the demands for these products in global markets.

JEL Classification: F14, M16, F31, K11.

\section{Introduction}

During the recent years, export development has attracted huge attention of researchers as they have found the crucial benefits of export development in the economic growth of different countries. The benefits can be summarized as follows: (1) increasing the employment, (2) providing a comparative advantage in the production of export products, (5) achieving higher efficiency and increasing the productivity of production factors, (4) optimal use of actual and potential facilities, (6) increasing the competition between producers and improving the quality of products, (7) using advanced technology, (8) attracting foreign investment and (9) expansion of domestic markets (Balasa, 1978). High-tech exports also come with additional benefits which stems from the industrial activities and their crucial roles on other sectors of the economy such as increasing the productivity and expansion of businesses (Gani, 2009). Accordingly, many economic experts believe that future of economic developments depends on the growth of knowledge-based activities, including development of high-tech industries and their influence all areas of production and exports.

Today, competitiveness is an important factor in gaining more market share and exports development. In the meantime, national brand promotion can increase the national competitiveness and expand the amount of exports by reducing search costs, satisfying foreign customers, and maintaining their loyalty (Okten, 2019). Thus, increasing the competitiveness, penetration in international markets and export growth have been considered impossible without creating a strong and positive national brand 
(Tan et al., 2015). However, the emphasis on the role of the national brand in the development of exports remains limited to theoretical issues, and to the best of our knowledge, there is no study on the impact of national brand on high-tech exports using empirical data. Therefore, we aimed to cover this research gap and attempted to study this issue in the form of an inter-country study including two groups of selected developing countries and selected developed countries during the period of 2011-2018.

In this paper, we review the literature, and provide the reader with preliminary intuition in section 2 . The fallowing section presents a background of the subject matter, and Section 4 explains the research methodology. Finally, the results are discussed, and the paper is concluded by giving few recommendations in Section 5 and 6, respectively.

\section{Literature Review}

\subsection{HIGH-TECH EXPORTS}

An evaluation of the structure of world commodity exports shows that global trade is moving towards high-tech products (Mehregan et al., 2011) because high-tech exports have less price and market fluctuations, providing a continuous and stable export condition. In addition, high-tech exports owing to their reliance on science and technology have greater profitability than the export of other products. Increasing the social, political and cultural influence of the exporting country in the destination country is another benefit of high-tech exports, which rarely occurs in the export of raw materials. Unlike high-tech products, raw and natural products can be easily found, produced, and exported to different areas and have many alternatives. More importantly, the export of raw materials happens once and the destination country does not need after-sale services. However, high technology exporting, especially capital equipment, requires a variety of services such as training, technical consulting, repair, assembly, etc., leading to double exports and higher returns. Additionally, high-tech exports are directly related to the growth of productivity and improving the economic growth. Preventing the sale of raw materials, diversifying exports and reducing the degree of vulnerability of the economy to external shocks are other benefits of developing high-tech exports (Tabaldi, 2011). Therefore, maximizing the benefits of exports in developing countries depends on changing their export structure in various fields such as turning exports based on simple goods, agricultural products, natural resources, and raw materials towards high-tech exports. For instance, recent achievements of the export development in Southeast Asia are partly attributed to using high-tech exports, new production methods, new management skills, new marketing methods, and national brand growth (Matthew and Naude, 2007).

Empirical evidence shows that most of the developing countries suffer from a solely dependence on exports of raw materials like oil, as the only comparative advantage. Similarly, crude oil stands for more than $90 \%$ of total export of Azerbaijan, Algeria, Iraq, Kuwait and Venezuela, more than $80 \%$ of exports of Saudi Arabia, Oman, Qatar, Nigeria and Yemen, and more than 70\% from Iran during the period of 20112018. However, only 10 percent of the total exports of "developed" oil-producing countries such as the United States were dependent on oil exports (World Bank Database, 2018). Various studies have tried to 
identify the reason for this difference in order to increase the high-tech exports and consequently accelerate the economic growth in developing countries. The most important factors are identified as follows:

1. Real exchange rate: Adjusting the exchange rate in proportion to the inflation rate increases the competitiveness of high-tech products in global markets and also, through increasing the export profitability, the incentive of companies to invest in high-tech industries increases, therefore, the total amount of exports would be increased to a great extent. (Hui et al., 2015).

2. Intellectual property rights: Since intellectual property rights is a complementary link in the innovation cycle, and granting the copyright and the following financial benefits will lead to the flourishing of creative ideas, innovative products and high-tech exports, supporting the intellectual property rights considering level of country's development, the ability to imitate, and size of the importing country's market, can have different effects on high-tech exports. On the other hand, in developing countries where people and companies often follow a strategy of imitation, enhancing intellect property rights prevent the dissemination and transfer of technology through reverse engineering and reduce the high-tech exports. (Bayraktutan and Bidirdi, 2018 and Kabaclarley et al., 2017).

3. Trade openness: growth of the economy by facilitating and accelerating process of importing intermediate goods, capital tools, reverse engineering, and imitating foreign technologies and their applications in the production process of high-tech industries can expand the exports of these industries. (Mehrara et al., 2017; Sanda and Kyokanel, 2014 and Tabaldi, 2011).

4. Attracting foreign direct investment: increasing the attraction of foreign direct investment, and providing the required financial resources for high-tech industries provide a great opportunity for acquiring technical knowledge, implementing new production methods and better management of multinational companies, consequently, establishing high-tech industries and increasing the exports of these industries (Garces and Adriatico, 2019; Bayracattan \& Bidirdi, 2018; Kabaclarli et al., 2017; Guckman \& Turn, 2013; Tabaldi, 2011).

The present study is focused on the impact of the national brand on high-tech exports, which is unprecedented. So, in the following, the concept of the national brand is defined and the mechanism of its impact on high-tech exports is explained. The concept of national branding was first added to the encyclopedia of management vocabulary by English researcher Anholt (2007). According to him, the national branding refers to creating people who pay attention to the success of a country and believe in its prospects. Accordingly, the national brand contains a special competitive identity for the products produced in each country, and can eliminate the existed misconceptions about a country, guide them, and highlight the country's position in the target markets (Anholt, 2007). In addition, the national brand concept is exactly the same as the brand concept, including identity and sustainable performance as a goods' quality indicator (Kim, 2006). 
Also, a positive national brand is a competitive advantage, in other words, a competitive identity that can develop businesses and attract more investments; promote the goals of the tourism industry and improve public diplomacy; advocate for the interests of the export industry and boost the national identity and self-esteem (Moylanen and Renisto, 2009). Contributing to economic growth, enhancing the reputation of product and service brands due to the umbrella nature of the national brand, attracting foreign knowledge and talents and increasing the soft power are other benefits of promoting the national brand (Acton, 2019). Therefore, the national brand as one of the main pillars of national reputation in areas such as public diplomacy, cultural relations, investment, export, tourism and economic development have attracted huge attention of researchers, and also can have positive effects on high-tech exports. Another reason for this huge impact is the increasing competition in global markets, which has made economic savings and cost reductions the top priorities for companies to overcome competitors and attract customers; however, retaining current customers costs much less than attracting new ones. (Papa and Custer, 2016). Also, increasing value of national brand by improving mental image of international audiences towards the products made in the brand's country, helps to maintain the loyalty of foreign customers (Vorm and Srivastava, 2014 and Gastafson et al., 2005).

In addition, improving the national brand by creating superior value for loyal foreign customers encourages them to pay more, with less sensitivity, to buy the brand of their choice which increases the demands of export for high-tech products (Ozakli and Baloglu, 2011; De Chernatoni and McDonald, 1992). From an economic point of view, improving the national brand image reduces the search costs for the consumer, internally (the time required to think about the product) and externally (the time required to select the product), causing an increase in the export of high-tech products (Barnes and Higgins, 2017). Therefore, similar to a low-quality product that does not have the possibility of a long-term and continuous presence in domestic and foreign markets, without creating a strong national brand, it is not possible for a country's high-tech products to be present and penetrate in international markets.

Increasing the value of a national brand by providing useful information to foreign customers helps them to purchase the best product and promotes high technology exports (Fetzcherian and Tonkar, 2010).

\section{Research Background}

The determinants of exports in general specifically high-tech exports have been studied precisely, and some of the most important ones are mentioned below. However, a scientific and systematic study of the impact of the national brand on high-tech exports using empirical data has rarely seen in these studies.

Garces and Adriatico (2019) studied the effect of FDI[1], energy investment, official development assistance (ODA), and official assistance for development and GDP[2] on high-tech exports in Philippine over the period of 1991-2016. Results showed that FDI and ODA had a positive and significant effect on high-tech exports. However, GDP has a negative impact on high-tech exports. In addition, Energy investment had no effect on high-tech exports development. 
Bayraktutan and Bidirdi (2018) studied the effect of the number of patents on the performance of highand medium-tech exports in developed and developing countries for the period of 1996-2012. The estimation results showed that the number of patents was one of the main determinant of high-and medium-tech exports in both groups of countries. Yet, the pull of the number of patents is higher in developing countries than the corresponding value in developed countries. While there is no short-term causality between the number of patents and high- and medium-tech exports, there is a short-term causality between fixed capital and FDI, and high- and medium-tech exports.

Sezer (2018), using panel data analysis, investigated the effect of $R \& D[3]$ costs and the number of R\&D eligible labor on high-tech exports in the BRICS[4] (Brazil, Russia, India, China, and South Africa) countries for the period of 1996-2014. Results showed that R\&D costs and the number of R\&D eligible labor have a positive effect on high-tech exports.

Kabaklarli et al. (2017), using panel data approach, analyzed the factors affecting high-tech exports in selected countries of the OECD[5] from 1989 to 2015. Results showed that enhancing the patent registration process and FDI plays an important role in boosting high-tech exports; however the economic growth and rate of financial return has no effect on high-tech exports.

Mehrara et al. (2017), considering the importance of high-tech export's role in economic growth, studied the determinants of high-tech exports in 24 developing countries over the period of 1996-2013 by using Bayesian model averaging approach (BMA) and the weighted-average least square (WALS). Results indicated that rule of law (period of institutional quality), human capital, imports (replacing economy openness), and GDP with $100 \%$ probability were the most important variables influencing high-tech exports in developing countries.

Suorsa (2017) investigated effect of national brand on Finnish food exports. Data was collected through interviews with food experts and managers of food export companies. Results showed that Finnish national brand and Finnish food culture were not internationally known. For this reason, some Finnish food exporters do not highlight the origin of their products, or attribute it to larger geographical areas such as Nordic countries to increase their exports, especially to distant markets. In addition, national brand of the exporting country is not the determinative factor in the decision to buy food, and the taste and quality of the food are much more important. Furthermore, results showed that although the Finnish national brand is not important in food marketing, the brand's value is largely based on facts.

Alagöz et al. (2016) studied the relationship between R\&D costs and high-tech export Advancement in E7 member countries (Indonesia, Brazil, Turkey, China, Russia, Mexico, and India). The results showed that China has the highest share of R\&D costs and high-tech exports among E7 countries.

Sandu and Ciocanel (2014) investigated the relationship between high-tech exports and some of the key drivers of innovation in EU countries. Results of the econometric data analysis showed that both public and private R\&D costs, human resources employed in scientific activities, and the tendency to develop the international business relationships, as the key drivers of innovation, have a clear relationship with 
increasing high-tech exports in the EU countries. In addition, R\&D costs of private organizations have a greater effect on high-tech exports in comparison with public organization R\&D costs.

Gökmen and Turen (2013), using panel data from 15 EU countries during 1995-2010, studied FDI, economic freedom, and human development variables' relationship with high-tech exports. Results indicated that this relationship is statistically positive and significant. In addition, the causality test results showed that FDI, economic freedom, and human development had a unilateral causality relationship with high-tech exports in the long-run.

Tebaldi (2011) investigated the factors affecting high-tech exports in selected countries during the period 1980-2008. Based on the results, human capital, FDI, and trade openness are the most important factors which influence the high-tech exports in global markets. Yet, the direct effect of institutions on high-tech exports was not confirmed. However, institutions may indirectly influence high-tech exports through influencing human capital and attracting FDI. Furthermore, other results of this study were that gross capital formation, savings, and macroeconomic fluctuations do not have a significant effect on high-tech exports.

A review of previous studies shows, they not only evaluated the impact of the brand on the export of some specific industries such as food, but also they studied the export of small and medium enterprises using historical data. However, determining the impact of national brand on high-tech exports using empirical data in the form of inter-country study is unprecedented. As discussed in the previous sections, strengthening the national brand could theoretically lead to the development of high-tech exports. Therefore, the present study tried to cover the identified research gap and provide a more accurate estimation of the national brand's impact on high-tech exports by empirically examining this issue for policy purposes.

[1] Foreign direct investment

[2] Gross domestic production

[3] Research and Development

[4] Is the acronym coined to associate five major emerging economies: Brazil, Russia, India, China, and South Africa

[5] The Organization for Economic Co-operation and Development

\section{Research Methodology}

This research is intended to be done because of its applicable and useful results. To make it crystal clear, the results can be applied to the growth of high-tech exports in selected countries. It is descriptiveanalytical in terms of nature since it describes and analyzes the relationship between the variables, using secondary statistics without interference and manipulation. We use multivariate regression analysis (the core of econometric studies), panel data approach, GMM, and Stata software to estimate the effect of national brand on high-tech exports. The statistical sample of this paper consists of 14 developing 
countries[6] (sample group) and 12 emerging developed countries[7] (control group) whose data are available over the period of 2011-2018.

\section{4-1. MODEL PRESENTATION}

The model used in this paper is a panel data type that can provide a more efficient estimation due to the limitation of the variance heterogeneity problem, decrease in the coherence between variables, and increase in the degree of freedom over cross-sectional and time series data (Baltaghi, 2005). The panel data consists of both static and dynamic types. The model of this paper is dynamic in which the dependent variable's lag appears as the explanatory variable on the right side to clear the relationships between the variables (Arellano and Bond, 1991). This is because many of the economic variables, including high-tech exports, are naturally dynamic, and their performance of the previous period can be extended to the next period.

However, in the dynamic panel model, due to the addition of the interrupt dependent variable, it is not possible to use conventional estimation methods such as ordinary least squares (OLS), least-squares dummy variables (LSDV), and generalized least squares (GLS). Indeed, the perturbation component correlates with the interrupt-dependent variable and the estimation results are distorted. Therefore, Arlano and Bond (1991) proposed an estimator called Generalized Method of Moments (GMM) which, not only solves correlation problem between the independent variable and the perturbation component, also it eliminates variables' indigenousness and variance heterogeneity of the model. This estimator works on both fixed and random effects and does not require the Hausman test because in dynamic panel models, there is a relationship between error term and explanatory variables (Hayashi, 2000). In addition, this method is often used when the number of cross-sectional variables $(\mathrm{N})$ is greater than the number of times and years $(T)(T<N)$, similar to the condition, which this study has been carried out.

With these explanations, the sub-form of the high-tech export equation inspired by the Sezer (2018), Bayraktutan and Bidirdi (2018), Kabaklarli et al. (2017), Mehrara et al. (2017), Alagöz et al. (2016), Sandu and Ciocanel (2014), Gökmen and Turen (2013), and Tebaldi (2011) works are presented as follows.

HTE $=f(N B, R E R, I P R$, OPEN, FDI $)(1)$

NB $\geq 0$, RER $\geq 0$, IPR $\geq 0$, OPEN $\geq 0$, FDI $\geq 0$

$\frac{\partial \mathrm{HTE}}{\partial \mathrm{NB}}>0, \frac{\partial \mathrm{HTE}}{\partial \mathrm{RER}}>0, \frac{\partial \mathrm{HTE}}{\partial \mathrm{IPR}}>0, \frac{\partial \mathrm{HTE}}{\partial \mathrm{OPEN}}>0, \frac{\partial \mathrm{HTE}}{\partial \mathrm{FDI}}>0$

$\log \left(\mathrm{HTE}_{\mathrm{it}}\right)=\beta_{0}+\beta_{1} \log \left(\mathrm{HTE}_{\mathrm{it}-1}\right)+\beta_{2} \log \left(\mathrm{NB}_{\mathrm{it}}\right)+\beta_{3} \log \left(\mathrm{RER}_{\mathrm{it}}\right)+\beta_{4} \log \left(\mathrm{IPR}_{\mathrm{it}}\right)$

$+\beta_{5} \log \left(\mathrm{OPEN}_{\mathrm{it}}\right)+\beta_{6} \log \left(\mathrm{FDI}_{\mathrm{it}}\right)+\mathrm{U}_{\mathrm{it}}(2)$

$\mathrm{U}_{\mathrm{it}}=\mathrm{v}_{\mathrm{i}}+\mathrm{e}_{\mathrm{it}}(3)$ 
In Equation 1, $t$ denotes time, $i$ refers to the since the logarithmic form represents the percentage change of the dependent variable vs the percentage change of the explanatory variable, all variables are logarithmic to simplify coefficients interpretation, and stands for model error term that includes countryspecific fixed effects $\left(\mathrm{v}_{\mathrm{i}}\right)$ and error residual term $\left(\mathrm{e}_{\mathrm{it}}\right)$. In addition, all variables are logarithmically assigned to simply interpret the coefficients since the logarithmic form represents the percentage change of the dependent variable vs the percentage change of the explanatory variable, all variables are logarithmic to simplify coefficients interpretation. The logarithmic form represents the percentage change of the dependent variable as the percentage change of the explanatory variable. The letter / before the variables also indicates the logarithmic variables.

HTE (high-tech export) has been considered as a dependent variable representing the percentage of hightech export of total manufactured exports for the selected country. $\mathrm{HTE}_{\mathrm{it}-1}$ is a high-tech export of last year, as an independent variable appears on the right side of the equation.

$\mathrm{NB}[8]$ is the explanatory variable that is used as the national brand value of the selected countries published by the Brand Finance Institute. It should be noted that the this Institute, established in 1996 and headquartered in the UK, is one of the trademark rating institutions in various fields, e.g. auto parts, information technology, civil engineering, food, etc. Each year, having measured the total value of brands available in different countries, the Institute calculates the brands' intangible asset value, and ranks and publishes them as the National Brand Value. In addition, the published index consists of three main sectors: (i) products and services, (ii) investment, (iii) society, which each of them are subdivided into tourism, market, government, people, and skills, and also the subdivisions are divided into individual criteria. Finally, the score for each criterion is calculated from 100, and by summing the scores of all criteria, the score of the overall national brand index is obtained, which is assigned a score of AAA+ (brand exceptional strength) to $d$ (brand failure). Therefore, based on the mechanism outlined above, with the improvement of the national brand, the high-tech export is expected to be expanded.

Yet, defining an appropriate model that can explain the changing behavior of high-tech export requires considering the other effective factors that are defined as control variables. These variables are selected based on the theoretical export principles and following empirical studies, and the principle of nonautocorrelation between the explanatory variables. However, since the mechanism of each variable's effect was is explained in the section of theoretical foundations, it is avoided to discuss it again here:

RER stands for the real exchange rate (Rasoulinezhad \& Kang, 2016), and is expected to have a positive effect on high-tech export.

IPR is the intellectual property rights following Bayraktutan and Bidirdi (2018) and Kabaklarli et al. (2017) study, in the research model.

OPEN denotes the economy's degree of openness that follows Mehrara et al. (2017), Sandu and Ciocanel (2014), and Tebaldi (2011) study, in the research model. 
FDI represents attraction of foreign direct investment follows the study Garces and Adriatico (2019), Bayraktutan and Bidirdi (2018), Kabaklarli et al. (2017), Gökmen and Turen (2013), and Tebaldi (2011).

In addition, high-tech export data, real exchange rates and the degree of Economy openness are from the World Bank database[9], national brand value data are from the Brand Finance Institute database[10], intellectual property rights[11] data are from the World Intellectual Property Organization database[12] and Foreign direct investment data have been extracted from the United Nations Conference on Trade and Development (UNCTAD) database.

[6]. Eight Islamic member states of the D8 (Indonesia, Iran, Bangladesh, Pakistan, Turkey, Malaysia, Egypt and Nigeria), and six member states of the Persian Gulf Cooperation Council (United Arab Emirates, Bahrain, Saudi Arabia, Oman, Qatar and Kuwait).

[7]. Seven developed economies of the G7 group (Germany, United States of America, United Kingdom, Italy, Japan, France, and Canada), and five emerging economies of the Brix Group (South Africa, Brazil, China, Russia and India).

[8]. National brand

[9]. http://data.worldbank.org/data-catalog/world-development-indicators

[10]. https://brandfinance.com

[11]. Intellectual Property

[12]. https://www.globalinnovationindex.org

\section{Results}

Since the usual econometric methods are based on the assumption of stationary variables, in case of non-stationary data, the mean, variance and autocorrelation structure change over time result in inaccurate t-test, F-test, and statistical inference, and thus, a false regression is possible. Therefore, it must be considered before estimating the static model of the variables. However, in the present study, since the study period is less than 10 years, no stationary test is necessary (Wooldrige, 2008).

Furthermore, since panel data is the result of combining the data of different regions (selected countries) over time (2011-2018), the capability of combining these data has been examined by performing the FLimmer test, which showed that the computational $\mathrm{F}$ values were higher than the table value. Therefore, the $\mathrm{HO}$ hypothesis (equality of $\mathrm{y}$-intercepts) was rejected, and the group effects (model estimation as panel data) were accepted.

Finally, the research model was estimated using GMM for each group of countries. Before the estimation, two tests were carried out to confirm the suitability of the GMM for estimating the model: First, the Sargan test was done to prove the validity condition of the over-diagnosis, i.e. the validity of the instrumental variables, whose $\mathrm{HO}$ indicates the appropriateness of the instrumental variables. In this study, the values greater than $5 \%$ possibility of Sargan statistic for both estimates indicated that the noncorrelation of the tools with error terms could not be rejected. As a result, the tools used in the model estimated model are valid. Secondly, the first-order AR(1) and the second-order AR(2) were applied, 
where according to Arellano and Bond (1991), in estimating GMM, error terms must have first-order serial correlation and no second-order serial correlation. Results showed that in both estimation models of the present model, AR(1) autoregressive coefficient was significant, and AR(2) autoregressive coefficient was not significant. Therefore, there is no explicit estimation bias in the dual states estimation, and the results are reliable. In addition, the results of the goodness-of-fit evaluation of the model showed that the $\mathrm{R}^{2}$ and adjusted $\mathrm{R}^{2}$ in both cases were close to 1 , proving the consistency of the empirical data with the conceptual model.

\section{Table 1: GMM Results of the Model Estimation}

Explanatory Variables Independent Variable

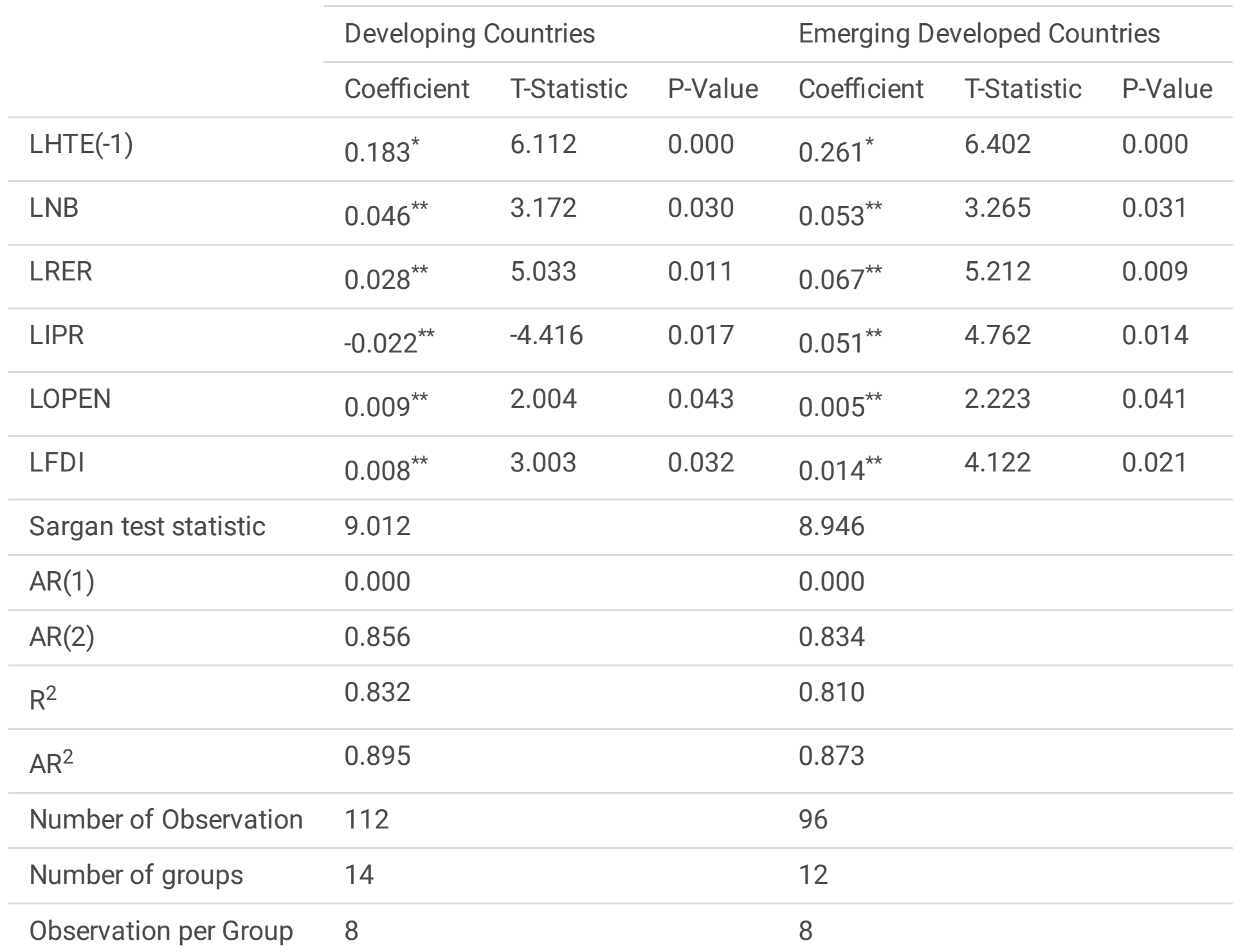

Source: Research findings ( $* 1, * \star 5, \star \star \star 10 \%$ significance level)

\section{Discussion}


The national brand has a positive and significant effect on high-tech exports in both groups of selected countries. The point is that the national brand highlight the international prestige of a country, and it is an important factor to attract the attention of audiences. Indeed, the increase of the country's prestige for high-tech products not only acts as a competitive advantage to retain previous customers, and attract new ones in global markets, but also it highly increases the exports. However, it should be mentioned that the estimated coefficient of this variable is higher in selected developed and emerging countries.

The real exchange rate has a positive and significant effect on high-tech exports in both groups of selected countries. The point is increase in the real exchange rate makes the high-tech industries' producers prefer to export their product to foreign markets instead of selling it in domestic ones, to earn a higher income. The estimated coefficient of this variable is higher in selected developed and emerging countries to such an extent that 1 percent increase in the real exchange rate in developed countries has led to a 0.067 percent increase in the share of high-tech exports in total factory exports; however, the corresponding coefficient in selected developing countries possess a lower value (0.028). This result can be attributed to the fact that in developed countries, high-tech industries are less dependent on imported inputs, therefore, rise of exchange rates and higher prices of imported inputs have a lower impact on hightech exports.

Intellectual property rights have a positive and significant effect on high-tech exports in selected developed and emerging countries, and a $1 \%$ improvement in intellectual property rights has resulted in a $0.051 \%$ increase in the share of high-tech exports in the total exports of their factories. Indeed, these countries have a greater potential for high-tech innovations and inventions owing to the high investment in research and development activities, and possessing highly qualified experts in different industrial fields. Thus, the protection of intellectual property rights is of paramount importance in exports development of high-tech industries. However, the impact of intellectual property rights on high-tech exports in developing countries is significantly negative. Empirical evidence shows that intellectual property rights in these countries are very weak, enabling people and companies to pursue a strategy of imitation. However, any strengthening of intellectual property rights can prevent the dissemination and transfer of technology through reverse engineering and reduce the share of high-tech exports in the total exports of their factories.

The economy openness degree has a positive and significant effect on high-tech exports in both groups of selected countries. The opening up of the economy not only has made it easier to access the imported inputs and new technical knowledge but also it has caused to identify the tastes and needs of customers in global markets, leading to the growth of high-tech exports and higher estimated coefficient in selected developing countries. Thus, a $1 \%$ increase in the degree of openness of the economy has increased the share of high-tech exports by $0.009 \%$ of the total exports of their factories, which is a larger number compared to the coefficient of $0.005 \%$ in developed and emerging countries. The reason is that developing countries are more dependent on import inputs and new technical knowledge required for high-tech production and exports, and the opening up of the economy has facilitated their imports. 
Attracting foreign direct investment has a positive and significant effect on high-tech exports in both groups of selected countries. In fact, attracting foreign investment from multinational companies equipped with more advanced technologies and new management methods has led to the growth of productivity of high-tech industries. In addition, most of the distribution channels in the global markets are owned by these multinational companies, which are well aware of foreign trade arrangements. As the results show, the estimated coefficient of this variable is higher in selected developed and emerging countries, and a $1 \%$ increase in their foreign direct investment attraction has increased the share of hightech exports from total factory exports by 0.041 percent, which is a larger number compared to the corresponding one for selected developing countries (0.008).

The effect of an intermittent dependent variable (share of high-tech exports of total factory exports in one period) on high-tech exports is positive and significant to such an extent that a $1 \%$ increase in the share of high-tech exports in the total exports of factories has led to 0.183 and $0.261 \%$ increase in developing, and developed and emerging countries in the fallowing period. The fact is the rise of high-tech exports in one period before the existence of a suitable platform push the industries for more high-tech exports in the next period.

\section{Conclusion}

Based on the results, the effect of the national brand on high-tech exports in both groups of the selected developing and emerging developed countries is positive and significant. Since the share of high-tech exports in developing countries is smaller and its development is more necessary and also the national brand value and its impact on high-tech exports is less significant, it is recommended that by providing knowledge-based activities such as educating the labor force, increasing R\&D budget, etc. So, a suitable platform for high-tech products would be provided. This reduces the risk of losing current customers; and also, through the word-of-mouth strategy, a powerful, distinctive, and popular brand could be introduced to attract potential customers and increase high-tech exports.

\section{Abbreviations}

GMM: Generalized method of moments

FDI: Foreign direct investment

ODA: Official development assistance

GDP: Gross domestic production

R\&D: Research and Development

BRICS: Is the acronym coined to associate five major emerging economies: Brazil, Russia, India, China, and South Africa. 
OECD: The Organization for Economic Co-operation and Development

BMA: Bayesian model averaging approach

WALS: weighted-average least square

E7: Member countries (Indonesia, Brazil, Turkey, China, Russia, Mexico, and India)

EU Countries: The EU countries are: Austria, Belgium, Bulgaria, Croatia, Republic of Cyprus, Czech

Republic, Denmark, Estonia, Finland, France, Germany, Greece, Hungary, Ireland, Italy, Latvia, Lithuania, Luxembourg, Malta, Netherlands, Poland, Portugal, Romania, Slovakia, Slovenia, Spain and Sweden.

OLS: Ordinary least squares

LSDV: Least-squares dummy variables

GLS: Generalized least squares

HTE: High-tech export

$\mathrm{HTE}_{\mathrm{it}-1}$ : High-tech export of last year

NB: National brand

RER: Real exchange rate

IPR: Intellectual property rights

OPEN: Openness

UNCTAD: United Nations Conference on Trade and Development

\section{Declarations}

Availability of data and materials: The data source is available in the text of the article

Competing interests: Declarations

Funding: Declarations

Authors' contributions: The authors' share is $50 \%, 30 \%$ and $20 \%$, respectively

Acknowledgements: Declarations

Authors' information: 


\section{References}

1. Alagöz, M., Akar, G. \& Akar, T. (2016). High technology export and R\&D expenditures: A study for E7 countries. International Journal of Economic, Commerce and Management, IV(11): 219-230.

2. Anholt, S. (2007). Competitive identity: The new brand management for nations, cities and regions. Hound mills, Basingstoke, Hampshire [England]; New York: Palgrave Macmillan.

3. Arellano, M. \& Bond, S. (1991). Some tests of specification for panel data: Monte Carlo evidence and an application to employment equations. Review of Economic Studies, 58(2): 277-297.

4. Balassa, B. (1978). Export and economic growth: Further evidence. Journal of Development Economics, 5(2): 181-189.

5. Baltagi, B. H. (2005). Econometric analysis of panel data. John Wiley \& Sons Inc, 3rd Edition, New York, USA.

6. Barnes, F. \& Higgins, D. M. (2017). Brand image, cultural association and marketing: 'New Zealand' butter and lamb exports to Britain, c. 1920-1938. Journal Business History, 62(1): 70-97.

7. Bayraktutan, Y. \& Bıdırdı, H. (2018). Innovation and high-tech exports in developed and developing countries. Journal of International Commerce, Economics and Policy, 9(03): 1-21.

8. Fetscherin, M. \& Toncar, M. (2010). The effects of the country of brand and the country of manufacturing of automobiles: An experimental study of consumers' brand personality perceptions. International Marketing Review, 27(2): 164-178.

9. Gani, A. (2009). Technological achievement, high technology exports and growth. Journal of Comparative International Management, 12(2): 31-47.

10. Garces, E. J. \& Adriatico, C. (2019). Correlates of high technology exports performance in the Philippines. Open Journal of Social Sciences, 7(5): 215-226.

11. Gökmen, Y. \& Turen, U. (2013). The determinants of high technology exports volume: A panel data analysis of EU-15 countries. International Journal of Management, Economics and Social Sciences, 2(3): 217-232.

12. Gustafsson, A., Johnson, M. D. \& Roos, I. (2005). The effects of customer satisfaction, relationship commitment dimensions, and triggers on customer retention. Journal of Marketing, 69(4): 210-218.

13. Hooy, C. W., Law, S. H. \& Chan, T. H. (2015). The impact of the Renminbi real exchange rate on ASEAN disaggregated exports to China. Economic Modelling, 47: 253-259.

14. Hultén, B. (2011). Sensory marketing: the multi-sensory brand-experience concept. European Business Review, 23(3): 256-273.

15. Kabaklarli, E., Duran, M. S. \& Üçler, Y. T. (2017). The determinants of high-technology exports: A panel data approach for selected OECD countries. Dubrovnik International Economic Meeting, 3(1): 888900.

16. Kim, Y. (2006). Do South Korean companies need to obscure their country-of-origin image? A case of Samsung. Corporate Communications an International Journal, 11(2): 126-137. 
17. Matthee, M. \& Naudé, W. A. (2007). The determinants of regional manufactured exports from a developing country, Helsinki, United Nations University, World Institute for Development Economics Research, WIDER Research Paper No. 2007/10.

18. Mehrara, M., Seijani, S. \& Rezazadeh Karsalari, A. (2017). Determinants of high-tech export in developing countries based on bayesian model averaging. Zbornik Radova Ekonomskog Fakultet au Rijeci, 35(1): 199-215.

19. Mehregan, N., Dehghanpur, M. R. \& Dehmoobed, B. (2011). Factors that effect on hi-tech industries export. Journal of Science and technology policy, 3(4): 69-83.

20. Moilanen, T. \& Rainisto, S. (2009). How to brand nations, cities and destinations; a planning book for place branding. cromwell press Itd, Trowbridge, Wiltshire.

21. Ökten. N. Z., Okan, E. Y., Arslan, U. \& Güngör, M. O. (2019). The effect of brand value on economic growth: A multinational analysis. European Research on Management and Business Economics, 25(1): 1-7.

22. Pappu, R. \& Quester, P. (2016). How does brand innovativeness affect brand loyalty? European Journal of Marketing, 50(1/2): 2-28.

23. Rasoulinezhad, E. \& Kang, G. S. (2016). A panel data analysis of South Korea's trade with OPEC member countries: The gravity model approach. Iranian Economic Review, 20(2): 203-224.

24. Sandu, S. \& Ciocanel, B. (2014). Impact of R\&D and Innovation on high-tech export. Procedia Economics and Finance, 15(14): 80-90.

25. Sezer, S. (2018). Impacts of R\&D expenditures on high technology product exports in BRICST countries. The Journal of Social Sciences Research, 4(10): 165-175.

26. Shahabadi, A. \& Samari, H. (2014). Innovation and exports based on high technology: Comparison of the Islamic Republic of Iran with vision plan countries. Roshd-e-Fanavari, 10(38): 45-54.

27. Suorsa, E. (2017). Country branding in export promotion: Case food from Finland. Type of degree master's thesis entrepreneurship, Jyväskylä University School of Business and Economics.

28. Tan, V., Ochoa, J. J., Langston, C. \& Shen, L. (2015). An empirical study on the relationship between sustainability performance and business competitiveness of international construction contractors. Journal of Cleaner Production, 93(1): 273-278.

29. Tebaldi, E. (2011). The determinants of high-technology exports: A panel data analysis. Atlantic Economic Journal, 39(4): 343-353.

30. Usakli, A. \& Baloglu, S. (2011). Brand personality of tourist destinations: An application of selfcongruity theory. Tourism Management, 32(1): 112-114.

31. Wooldrige, J. M. (2008). Introductory Econometrics: A Modern Approach. 4th Edition.

32. Worm, S. \& Srivastava, R. K. (2014). Impact of component supplier branding on profitability. International Journal of Research in Marketing, 31(4): 409-424. 